Marquette University

e-Publications@Marquette

Economics Faculty Research and Publications

Economics, Department of

9-1-2009

\title{
Trade Openness, Capital Mobility, and the Sacrifice Ratio
}

Joseph P. Daniels

Marquette University, joseph.daniels@marquette.edu

David D. VanHoose

Baylor University

Accepted version. Open Economics Review, Vol. 20, No. 4 (September 2009): 473-487. DOI. (C) 2009 Springer. Used with permission.

Shareable Link. Provided by the Springer Nature SharedIt content-sharing initiative. 


\title{
Trade Openness, Capital Mobility, and the Sacrifice Ratio
}

\author{
By Joseph P. Daniels ${ }^{\dagger}$ and David D. VanHoose ${ }^{\ddagger}$
}

This paper develops and evaluates empirically the implications of a theoretical model of an open economy in which variations in both trade openness and capital mobility can influence the sacrifice ratio. Key predictions forthcoming from the model are that both forms of globalization can independently affect the sacrifice ratio, once the influences of the level of central bank independence and the degree of wage stickiness in nations' economies are taken into account. Examination of cross-country data encompassing 58 disinflations for 16 countries yields evidence consistent with these essential predictions of the theoretical framework.

\section{Introduction}

The path-breaking work of Romer (1993) highlighted an apparent inverse relationship in cross-country data between the degree of openness to international trade and the inflation rate. Romer's suggested explanation for this relationship is that increased trade openness exposes a nation to greater negative terms-of-trade effects resulting from domestic output expansions, thereby reducing the incentive for a central bank to engage in inflationary policymaking. Lane (1997) supplemented this rationale by proposing that increased trade openness reduces the potential output gains from unexpected inflation in non-traded-goods sectors characterized by imperfect competition and sticky product prices. In addition, Karras (1999) argued that greater indexation of nominal wages to unexpected inflation in response to increased trade openness could also reduce the incentive for central banks to inflate.

Temple (2002), however, questioned the relevance of explanations relying on a presumption that increased trade openness reduces the sacrifice ratio, because analysis of cross-country data failed to reveal such a relationship. Indeed, Daniels et al. (2005) have recently offered evidence indicating that once the role of central bank independence is considered, increased trade openness is associated with an increase in the sacrifice ratio, a result consistent with the analysis of Rogoff (2006), enunciations of some policymakers, such as Bean (2006), and evidence provided by Duca and VanHoose (2000) indicating that increases in product-market competition from both domestic and international sources have contributed to a shallower US Phillips curve. This finding is obviously at odds with a standard Barro and Gordon (1983) interpretation, although Daniels and VanHoose (2006) have provided a theoretical rationale for how increased trade openness could both raise the sacrifice ratio and reduce 
equilibrium inflation when imperfectly competitive product markets are included in an openeconomy Barro-Gordon analysis. Furthermore, Bowdler (2004) suggests that the nature of the trade openness-sacrifice ratio relationship may depend on the exchange-rate regime that is in place.

Separately, an additional line of research has focused on the other key aspect of globalization, capital mobility, and its relationship with both the sacrifice ratio and inflation. Gruben and McLeod $(2002,2004)$ suggest that increased capital mobility may act as a policy commitment mechanism that yields lower equilibrium inflation and present evidence supporting a disinflationary role for higher capital mobility. At the same time, however, work by Razin and Yuen (2002), Loungani, Razin, and Yuen (2001), and Razin and Loungani (2005) has suggested a positive relationship between capital mobility and the sacrifice ratio-again, a result inconsistent with a narrow Barro-Gordon-style interpretation. As a rationalization of how greater capital mobility could simultaneously contribute to lower inflation while increasing the sacrifice ratio, Razin and Loungani suggest that globalization may have boosted policymakers' loss weight on inflation and thereby induced lower equilibrium inflation.

Clearly, there remains a wide array of views regarding the effects of globalization on the sacrifice ratio and the relationship between these effects and the trade openness-inflation and capital mobility-inflation relationship. Some have, for instance, questioned whether the trade openness-inflation relationship either may be illusory, as suggested by Terra (1998), or may have shifted or even broken down since the early 1990s, as argued by Bleaney (1999). Indeed, Ball (2006) questions whether there is sufficient evidence to conclude, at least for the USA, that either trade openness or capital mobility is related to either the sacrifice ratio or inflation.

In light of these conflicting views, further exploration of the effects of greater trade openness and capital mobility is clearly warranted. In this paper, our objective is to investigate the separate and combined effects of both potential manifestations of globalization-increased trade openness and greater capital mobility—on the sacrifice ratio. We develop a simple openeconomy model that incorporates both openness to trade and the mobility of capital, and we analyze its predictions regarding effects of both forms of globalization on the sacrifice ratio. As emphasized with respect to trade openness by Daniels and VanHoose (2006) and with regard to capital mobility by Loungani et al. (2001), the extent to which nominal rigidities are a prevalent feature of a nation's economy has a critical bearing on how globalization affects the sacrifice ratio. Thus, we utilize a model in which a portion of firms utilizes nominal wage contracts and in which remaining firms do not. 
Our consideration of wage contracts as a source of nominal rigidity differs from the recent emphasis on price stickiness in much of the recent literature. In part, this choice is based on evidence that nominal wage rigidities are an important factor in the openness-inflation relationship (see Daniels et al. 2006). More generally, however, this choice reflects our fundamental agreement with Cukierman (2004), who argues out that adding product-price stickiness to input-price stickiness arising from nominal wage contracts ultimately adds little of fundamental importance to the nature of analysis of trade-offs faced by policymakers. ${ }^{1}$ Indeed, consistent with Cukierman's point, our model yields sacrifice-ratio implications for firms utilizing nominal wage contracts that are analogous to those obtained by Razin and Yuen (2002), Loungani et al. (2001), and Razin and Loungani (2005) in their sticky-price-based analyses of the openness-sacrifice ratio relationship. Nevertheless, our inclusion of firms that face no direct nominal wage rigidities_-but which nonetheless confront spillovers created by nominal wage rigidities at other firms in the economy, as in Duca (1987) and Duca and VanHoose (2001) _ allows for partial price adjustment that generalizes our analysis of the effects of greater capital mobility and its interaction with impacts of increased trade openness.

The next section presents our theoretical framework, and Section 3 investigates its implications for the relationships among trade openness, capital mobility, and the sacrifice ratio. Section 4 explores the empirical evidence regarding these relationships. Section 5 summarizes our conclusions.

\section{A simple open-economy model}

The theoretical model combines elements of the framework utilized by Benavie (1983) and Daniels (1997) and the model developed in Daniels and VanHoose (2006). There is a large, fixed number of atomistic firms, indexed $i$, distributed uniformly along a unit interval. In a portion, $\Omega$, of firms, nominal wages are set in advance of labor-market clearing. In the portion of firms, $1-\Omega$, that do not utilize such contracts, spot labor markets determine nominal wages. In a closed-economy version of this type of model, Duca and VanHoose (2001) have shown that if risk-neutral firms and risk-averse workers face common aggregate shocks and diverse firmspecific disturbances, the contract share of firms $\Omega$ typically lies between zero and unity but rises as the volatility of aggregate shocks increases relative to the variability of firm-specific disturbances. To focus on the issues at hand, we treat $\Omega$ as an exogenous parameter and thereby abstract from considerations of shocks that can affect the share of firms with nominal wage contracts.

Daniels, VanHoose 3 
The output produced by a given firm $i$ is given by

$$
y_{i}=\alpha l_{i}
$$

where $y_{i}$ is the log of output and $l_{i}$ is the log of employment at firm. The demand for the output of a domestic firm in sector $i$ as a share of aggregate domestic output is

$$
y_{i}-y=-\varepsilon\left(p_{i}-p\right),
$$

where $y \equiv \int_{0}^{1} y_{i} \mathrm{~d} i$ is the log of aggregate domestic output, $p \equiv \int_{0}^{1} p_{i} \mathrm{~d} i$ is the log of the aggregate domestic price level, and $\varepsilon>1$ is the elasticity of demand for the output of firms in sector $i$ of the domestic country.

The domestic nation's income-expenditure equilibrium condition [for a derivation of this Cobb-Douglas approximation, see, for instance, Canzoneri and Henderson (1991), or Bryson et al. (1993)] is given by

$$
y=\eta\left(p^{*}+s-p\right)+(1-\beta) y+\beta y^{*}-\delta\left[r-\left(p_{+1}^{e}-p\right)\right] ;
$$

where the average propensity to import, $\beta$, is a fraction; $\eta$ is the elasticity of desired spending with respect to the real exchange rate; $p^{*}$ is the log of the aggregate foreign price level; $s$ is the $\log$ of the domestic currency price of foreign currency; $y^{*}$ is the log of aggregate foreign output; $\delta$ is the semi-elasticity of domestic spending with respect to the domestic real interest rate; $r$ is the domestic nominal interest rate, and is the current expected value of the log of the price level in the next period.

Domestic money market equilibrium is given by

$$
m-p=\sigma y-\gamma r-\xi\left(r^{*}+s_{+1}^{e}-s\right),
$$

where $m$ is the log of the money stock, $r^{*}$ is the foreign nominal interest rate, $s$ is the log of the nominal exchange rate measured in units of domestic currency per unit of foreign currency, and $s_{+1}^{e}$ is the current expected value of the log of the exchange rate in the following period. Including Eq. 4 would permit a thorough-going analysis of the implications of this model for equilibrium inflation in a setting in which the nominal money stock is an instrument of monetary policy. In a setting in which the instrument of monetary policy is the interest rate, Eq. 4 would play a role in determining the resulting endogenous quantity of money.

The balance-of-payments equilibrium condition is ${ }^{2}$

$$
(1+\eta)\left(p^{*}+s-p\right)-\mu y+\theta \kappa r-\theta \psi\left(r^{*}+s_{+1}^{e}-s\right)+\varphi y^{*}=0,
$$

where $\mu, \theta, \kappa, \psi$, and $\varphi$ are nonnegative structural parameters. Note that if $\kappa=\psi$ and $\mu=\varphi$, then domestic and foreign bonds are perfect substitutes. If additionally the limiting case holds in which $\theta \rightarrow \infty$, then there is also complete capital mobility, and the uncovered interest 
parity condition is satisfied; that is, $r=r^{*}+s_{+1}^{e}-s$. More generally, a higher value of $\theta$ indicates an increase in the degree of capital mobility irrespective of the substitutability of domestic and foreign bonds, as long as $\kappa>0$ and $\psi>0$.

Specifying analogous structural relationships for a foreign nation would yield a twocountry framework in which $y^{*}, p^{*}$, and $r^{*}$ would be endogenous variables, but here we assume the output and prices abroad are exogenously determined. Henceforth, the foreign money stock, foreign price level, and foreign output are normalized at unity, so that $p^{\star}$ and $y^{\star}$ equal zero, and $r^{*}$ is assumed equal to $\rho$, a constant world interest rate.

Using Eqs. 5, 3, 2, and 1 in the profit function, $P_{i} Y_{i}-W_{i} L_{i}$, yields the labor demand function for a firm $i$ (with the intercept suppressed because it plays no role in our subsequent analysis):

$$
l_{i}^{d}=\frac{-\beta \varepsilon \omega\left(w_{i}-p\right)-\Theta p+\delta(1+\eta+\theta \psi) p_{+1}^{e}+\eta \theta \psi\left(\rho+s_{+1}^{e}\right)-\Lambda r}{\beta(\alpha+\varepsilon \omega-\alpha \varepsilon \omega)},
$$

where $w_{i}$ is the log of the nominal wage for the firm, $\omega \equiv 1+\eta(1-\mu)+\theta \psi, \Theta \equiv$ $\delta(1+\eta+\theta \psi)+\eta \theta \psi$, and $\Lambda \equiv \delta(1+\eta+\theta \psi)+\eta \theta \kappa$. Workers can consume domestic and foreign goods, so labor supply to firms depends on the real wage computed in terms of the overall price workers pay for a basket of both domestic and foreign goods:

$$
l_{i}^{s}=\lambda\left[w_{i}-(1-\beta) p-\beta s\right],
$$

where $\lambda>0$. Thus, for firms with or without nominal wage contracts, the full-information, market-clearing wage satisfies Eqs. 6 and 7 simultaneously and equals

$$
\widehat{w}_{i}=\frac{[\beta(1-\beta) \lambda(\alpha+\varepsilon \omega-\alpha \varepsilon \omega)+(\beta \varepsilon \omega-\Theta)] p+\delta(1+\eta+\theta \psi) p_{+1}^{e}+\beta^{2} \lambda(\alpha+\varepsilon \omega-\alpha \varepsilon \omega) s+\eta \theta \psi\left(\rho+s_{+1}^{e}\right)-\Lambda r}{\beta[\lambda(\alpha+\varepsilon \omega-\alpha \varepsilon \omega)+\varepsilon \omega]} .
$$

Substitution of Eq. 8 into either Eq. 6 or 7 and the result into Eq. 1 yields output of a noncontract firm with market-clearing $(\mathrm{mc})$ wages:

$$
y_{i}^{m c}=\frac{\alpha\{[1-\lambda(1-\beta)] \beta \varepsilon \omega-\Theta\} p+\lambda \alpha \delta(1+\eta+\theta \psi) p_{+1}^{e}+\beta^{2} \lambda \alpha(\alpha+\varepsilon \omega-\alpha \varepsilon \omega) s+\lambda \alpha \eta \theta \psi\left(\rho+s_{+1}^{e}\right)-\lambda \alpha \Lambda r}{\beta[\lambda(\alpha+\varepsilon \omega-\alpha \varepsilon \omega) \varepsilon \omega]} .
$$

Thus, the output of firms with market-determined nominal wages naturally depends on the current price level, anticipated exchange rate, and interest rate and on the anticipated future price level and exchange rate.

For the fraction, $\Omega$, of firms with nominal wage contracts, if the contract wage is equal to the expected value of the market clearing wage, substituting the expectation of Eq. 8 into 6 and the result in Eq. 1 yields output of a firm with wage contracts, given by 


$$
\begin{aligned}
y_{i}^{c}= & \frac{(\beta \varepsilon \omega-\Theta)[\lambda \Gamma+\varepsilon \omega] p-\alpha \beta \varepsilon[\beta(1-\beta) \lambda \Gamma+(\beta \varepsilon \omega-\Theta)] p^{e}+\alpha \beta \delta\{\lambda \Gamma+\varepsilon[\omega-(1+\eta+\theta \psi)]\} p_{+1}^{e}}{\beta^{2} \Gamma[\lambda \Gamma+\varepsilon \omega]} \\
& +\frac{\{\alpha \beta \eta \theta \psi[\lambda \Gamma+\varepsilon \omega]-\alpha \beta \varepsilon \eta \theta \psi\}\left(\rho+s_{+1}^{e}\right)-\lambda \alpha \beta^{2} \varepsilon \Gamma s^{e}-\alpha \beta \Lambda[\lambda \Gamma+\varepsilon \omega] r-\alpha \beta \varepsilon \Lambda r^{e}}{\beta^{2} \Gamma[\lambda \Gamma(\alpha+\varepsilon \omega-\alpha \varepsilon \omega)+\varepsilon \omega]},
\end{aligned}
$$

where $\Gamma \equiv(\alpha+\varepsilon \omega-\alpha \varepsilon \omega)$ and where $p^{e}$ and $s^{e}$ are the expectations of the current price level and exchange rate held by wage setters at the beginning of the current period based on prior information. Of course, these latter expectations play key roles in determining the contract nominal wage rate established at the outset of the period and hence influence equilibrium employment and output levels of firms utilizing wage contracts.

\section{Relating trade openness and capital mobility to the sacrifice ratio}

To explore the separate direct and interactive effects of trade openness and capital mobility on the sacrifice ratio, we note first that since firms behave identically, $y_{i}^{c}=y^{c}$ for all $i \in[0, \Omega]$, and $y_{i}^{m c}=y^{m c}$ for all $i \in(\Omega, 1]$. It follows that $y=(1-\Omega) y^{m c}+\Omega y^{c}$, so that responsiveness of aggregate output to a change in the domestic price level is given by $\frac{\partial y}{\partial p}=$ $(1-\Omega) \frac{\partial y^{m c}}{\partial p}+\Omega \frac{\partial y^{c}}{\partial p}$. Hence, the aggregate sacrifice ratio is the weighted average of the sacrifice ratio applicable to the portion of firms with spot-market-determined wages and the portion utilizing nominal wage contracts.

From Eqs. 9 and 10, the separate effects of an increase in the price level on output for firms with and without nominal wage contracts are given by

$$
\frac{\partial y^{m c}}{\partial p}=\frac{\alpha\{[1-\lambda(1-\beta)] \beta \varepsilon \omega-\Theta\}}{\beta[\lambda(\alpha+\varepsilon \omega-\alpha \varepsilon \omega)+\varepsilon \omega]},
$$

which is more likely to be positive if $\varepsilon$ is significantly greater than unity, so that product markets are highly competitive, and if $\lambda$ is relatively small, so that labor supply is relatively inelastic, and

$$
\frac{\partial y^{c}}{\partial p}=\frac{\beta \varepsilon \omega-\Theta}{\alpha \beta(\alpha+\varepsilon \omega-\alpha \varepsilon \omega)},
$$

which is also more likely to be positive if $\varepsilon$ is significantly greater than unity, so that there is a relatively significant degree of competition in product markets.

It is straightforward to show that $\frac{\left(\frac{\partial y^{c m}}{\partial p}\right)}{\partial \beta}>0$ and that $\frac{\left(\frac{\partial y^{c}}{\partial p}\right)}{\partial \beta}>0$. As in Daniels and VanHoose (2006), greater trade openness causes desired spending on domestic products to be responsive to changes in domestic income, which in turn causes profit-maximizing prices of 
firms in both labor-market-clearing and wage-contracting sectors to be less sensitive to a variation in aggregate domestic output. As a consequence, the aggregate price level is less responsive to a change in aggregate output, implying conversely that there is an increased sensitivity of output to a change in the price level. Together, these results imply that an increase in the average propensity to import makes desired expenditures on domestic output less sensitive to changes in domestic income, so that each firm's profit-maximizing price is less responsive to a change in aggregate domestic output. Thus, greater trade openness unambiguously boosts the aggregate sacrifice ratio.

The effects of increased capital mobility in this model are less clear-cut. For firms at which contracts set nominal wages in advance of product-market clearing, cumbersome computations verify that, for $\psi>0$, the sign of $\frac{\left(\frac{\partial y^{c}}{\partial p}\right)}{\partial \theta}$ hinges in large part on the interest-rate sensitivity of aggregate demand relative to the real-exchange-rate responsiveness of domestic demand. This conclusion is analogous to that derived by Loungani, Razin, and Yuen (2001) in the context of a combined flexible-price/sticky-price framework. As in their model, in the portion of the economy that is not directly constrained by nominal rigidities, there is greater scope for interest-rate and real-exchange-rate adjustments that in turn feed back to induce price and wage adjustments at these firms. In contrast to the economy-wide sticky-price settings considered by Razin and Yuen (2002) and Razin and Loungani (2005), which give rise to an unambiguously positive value for $\frac{\left(\frac{\partial y^{c}}{\partial p}\right)}{\partial \theta}$, wage and price adjustments at firms with marketdetermined wages spill over to influence prices at firms utilizing nominal wage contracts. As a consequence, the relative sensitivities of aggregate demand to interest-rate and real-exchangerate variations are crucial determinants of the responsiveness of output to the price level at firms with market-clearing wages. It can be shown that, in accord with the conclusions of Loungani et al. greater capital mobility boosts the sacrifice ratio-that is, $\frac{\left(\frac{\partial y^{c}}{\partial p}\right)}{\partial \theta}>0$-for parameter configurations $\psi$ and $\delta$ that are sufficiently large, so that there is a relatively high interest sensitivity of domestic and foreign asset demands and a relatively large interest responsiveness of desired domestic expenditures, and in which $\eta$ is sufficiently small, so that desired domestic spending is relatively unresponsive to variations in the real exchange rate.For the portion of the economy comprised of firms with market-determined wages, the sign of $\frac{\left(\frac{\partial y^{c m}}{\partial p}\right)}{\partial \theta}$ is highly ambiguous. At firms with market-clearing wages, adjustments of product prices and nominal wages are restrained only to the extent that spillovers are created by the failure of wages to 
adjust at firms with nominal wage contracts. Although interactions among the relative

magnitudes of $\lambda, \psi, \delta$, and $\eta$ determine the sign of $\frac{\left(\frac{\partial y m c}{\partial p}\right)}{\partial \theta}$ in this case as well, the interplay between fully adjusting prices and wages-again, subject to spillovers from firms with nominal wage contracts-yields complicated effects of prices on output that are difficult to disentangle.

The upshot of this analysis is that to the extent that our model yields a prediction about how greater capital mobility is likely to influence the sacrifice ratio, this prediction depends crucially on the labor supply elasticity, the interest-rate sensitivities of domestic and foreign asset demands, and the interest-rate responsiveness of desired domestic expenditures. Under certain parameter configurations we can obtain a definite prediction that increased capital mobility is likely to generate a rise in the sacrifice ratio in nations in which nominal rigidities are an important feature. In nations experiencing nominal rigidities but contrary parameter configurations, however, the opposite effect could emerge. In countries in which significant portions of firms charge market-determined product prices and pay market-determined wages, the model yields no definite theoretical predictions regarding the effects of greater capital mobility on the sacrifice ratio. The model does, however, yield more straightforward implications regarding the effects that an increased degree of capital mobility has on the impact of trade

openness on the sacrifice ratio-that is, the sign of $\frac{\partial^{2}\left(\frac{\partial y^{m c}}{\partial p}\right)}{\partial \beta \partial \theta}$. For both firms with and without nominal wage contracts, greater capital mobility enhances the positive effect of trade openness on the sacrifice ratio if $\psi$ and $\delta$ are sufficiently large and $\eta$ is sufficiently small. Thus, a reinforcing effect of capital mobility on the sacrifice-ratio impact of trade openness is also more likely if there is a relatively high interest sensitivity of domestic and foreign asset demands and a relatively large interest responsiveness of desired domestic spending.

Greater trade openness does nothing to clear up the theoretical ambiguities of the effects of greater capital mobility on the sacrifice ratio. Consequently, the theoretical model offers no clear-cut predictions regarding whether or not increased trade openness may or may not reinforce the impact of greater capital mobility on the sacrifice ratio. ${ }^{3}$

\section{Empirical implications and evidence}

Although the theoretical model does not resolve all of the ambiguities regarding trade and capital openness and their impact on the sacrifice ratio, the forgoing discussion yields three empirical implications: 
1. Taking into account the effect of central bank independence, increased trade openness makes output more price-sensitive and consequently raises the sacrifice ratio;

2. Higher capital mobility generally has uncertain affects on the sacrifice ratio, but in nations in which the use of nominal wage contracts is more widespread, greater capital mobility is more likely to boost the sacrifice ratio if domestic spending is relatively responsive to interest-rate changes but relatively unresponsive to real-exchange-rate variations; and

3. If domestic expenditures are relatively sensitive to interest-rate variations but relatively insensitive to changes in real exchange rates, higher capital mobility is likely to reinforce the positive effect of increased trade openness on the sacrifice ratio.

Our empirical models do not attempt to measure relative responsiveness of aggregate spending to interest-rate and exchange-rate variations across countries. We do, however, utilize measures of trade openness, capital mobility, central bank independence, and wage duration in an attempt to evaluate the independent and interactive effects of these variables on the sacrifice ratio in cross-country data. Our contribution to the existing literature, therefore, is to examine the direct impact of both capital and trade openness on the sacrifice ratio while also controlling for other important conditioning effects such as central bank independence and wage duration.

\subsection{Data}

We employ the data made available by Temple (2002) and Daniels et al. (2005), taken from Ball (1994), to test our hypotheses regarding the sacrifice ratio. This data set includes estimates of the sacrifice ratio (SAC) for 58 disinflationary periods occurring in 16 moderate inflation OECD economies from 1960 through the 1980s, initial inflation preceding the disinflationary episode, the change in inflation during the disinflationary period (Inflation $\Delta$ ), the length of the deflationary period (Length), and a measure of wage contract duration (Wdur). We augment this data with several other variables. First, we add the degree of central bank independence (CBI), taken from Franzese (2002), which is a weighted average of legal independence, a characterization of independence based on answers to a survey completed by individuals at central banks (Cukierman 1992), economic independence, political independence (Grilli et al. 1991), and Bade and Parkin's (1982) index of central bank independence.

Following the literature, first motivated by Romer (1993), we measure trade openness (Trade) with a ratio of the sum of exports and imports to GDP. This ratio is averaged over the sample period thereby capturing only the cross-country variation in trade openness. Consistent 
with our utilization of a de facto measure of trade openness, we also use a de facto measure of capital mobility (Capital), which is the average of the sum of total capital inflows and outflows as a percentage of GDP. Data on trade flows and capital flows are taken from the International Monetary Fund's International Financial Statistics. Table 1 contains descriptive statistics on the sample data.

As discussed above, the data on sacrifice ratios are for specific episodes of disinflation. Hence, dynamic panel models are not appropriate, and we conduct our empirical tests using OLS. In addition, some of the independent variables, such as CBI, WDUR, and the openness measures, are time-invariant, and as a consequence fixed-effects models are also not appropriate. Regression results are provided in Table 2 and discussed in the next section.

\subsection{Trade openness and the sacrifice ratio}

Daniels et al. (2005) examine the impact of trade openness on the sacrifice ratio using the average of imports as a percentage of GDP. They show the importance of accounting for the interaction of $\mathrm{CBI}$ and openness and suggest testing for outliers in the data. We employ the same measures for the sacrifice ratio, but we measure trade openness as the average of the sum of imports and exports as a percentage of GDP. Following Daniels et al. we test for outliers using the DFITS test, Cook's distance test, and Welsch's distance test, and our results similarly identify Germany's 1973-1978 disinflation episode as an outlier. We drop this single observation from all of our regression models.

The results in columns 1 and 2 of Table 2 reaffirm Daniels et al.'s conclusion that the coefficient of trade openness is insignificant (column 1) unless its interaction with central bank independence is included. Column 2 includes this interaction, with the results that the coefficient on trade openness is positive and statistically significant, while the coefficient of the interaction term is negative and significant. Hence, we re-attain the Daniels et al. result that trade openness and the sacrifice ratio are positively related and greater $\mathrm{CBI}$ reduces the effect of trade openness on the sacrifice ratio.

\subsection{Trade openness, capital mobility, and the sacrifice ratio}

Aizenman and Noy (2004) examine the correlation among financial and trade openness, measured as the sum of capital inflows and outflows as a percentage of GDP and as the sum of imports and exports as a percentage of GDP, respectively. They show that there is a linear twoway feedback relationship among the two openness variables. This simultaneous correlation between the two openness variables is, of course, problematic in our empirical study making it 
difficult if not impossible to isolate the individual effects of trade openness and capital mobility. ${ }^{4}$ This problem is compounded by the fact that some of our variables, $\mathrm{CBI}$ and wage duration in particular, have limited variability within our data set. One method of dealing with this problem would be to expand the sample, not only increasing our degrees of freedom but also the variation of key variables. However, combining estimates of the sacrifice ratio, central bank independence and (especially) wage duration is problematic and limits our ability to expand the data, resulting in less than 60 usable observations. Hence, to examine the relationship between capital mobility and the sacrifice ratio, we reduce colinearity among the variables by dropping the interaction term between trade openness and central bank independence in the remaining columns of Table 2 and in columns 3, 4 , and 5 of Table 2 we replace trade openness with capital mobility as the single measure of international openness. Furthermore, we examine the interaction of capital mobility with $\mathrm{CBI}$ and wage duration separately. ${ }^{5}$ In column 3 , the effect of capital mobility on the sacrifice ratio is positive but statistically insignificant. In column 4, we find that accounting for an interaction between capital mobility and central bank independence leads to the implication of a positive (statistically significant at the $10 \%$ level) effect of greater capital mobility on the sacrifice ratio. As with the trade openness measure of international openness, however, the impact of capital mobility on the sacrifice ratio is significantly reduced by increased central bank independence.

In comparing columns 3 and 4 to columns 1 and 2 , it is tempting to conclude that in light of the relatively high bilateral correlation between trade openness and capital mobility, the empirical results suggest that both international openness measures are essentially substitutable. Recall, however, that the theoretical model suggests a positive interaction between the degree of wage stickiness and the sacrifice-ratio effect of greater capital mobility. Column 5 includes an interaction between our measures of these two variables. Doing so results in a statistically insignificant estimated effect of capital mobility on the sacrifice ratio but a positive (statistically significant at the $10 \%$ level) interactive effect of wage duration and capital mobility. Thus, consistent with the theory, the degree of wage stickiness plays a key role in conditioning capital mobility's sacrifice-ratio impact.

The relatively high correlation between our trade openness and capital mobility measures suggests that including both as independent variables is a problematic exercise. Nevertheless, for the sake of completeness in examining the implications forthcoming from the data, in columns 6,7 , and 8 of Table 2 we include both international openness measures. The coefficient estimate for capital mobility is positive but statistically insignificant in column 6 . When the interaction between capital mobility and wage duration is added in column 7 , the direct effect 
of capital mobility on the sacrifice ratio remains statistically insignificant ( $p$-value of $20 \%$, twotailed test). Consistent with theory, however, the effect of an interaction between capital mobility and wage duration is positive and significant, indicating that a greater degree of wage rigidity tends to bring about a positive effect of increased capital mobility on the sacrifice ratio.

Nevertheless, in both of the models for which results are displayed in columns 6 and 7, tests of a joint significance of trade and capital mobility effects on the sacrifice ratio are insignificant.

Column 8 reports the results of adding an interaction term between trade openness and capital mobility. Neither the openness measures nor the interaction term are significant, nor are they jointly significant. Thus, the empirical results do not resolve the theoretical prediction indicating that greater capital mobility potentially could reinforce the sacrifice-ratio impact of increased trade openness.

What can we conclude from these results? First, consistent with earlier work by Daniels et al. (2005) and with the model developed in this paper, increased openness to international trade has a positive effect on the sacrifice ratio once the dampening effect of greater central bank independence $(\mathrm{CBI})$ is taken into account. Second, consistent with evidence offered by Razin and Loungani (2005), accounting for the conditioning effects of CBI implies that greater capital mobility also boosts the sacrifice ratio. Third, the finding that greater wage stickiness boosts the positive effect of greater capital mobility on the sacrifice ratio is consistent with the prediction of our theoretical model when aggregate spending is more sensitive to interest-rate variations than to exchange-rate variations. This finding highlights the importance of considering potential effects specific to increased capital mobility rather that considering the impact of "globalization" to be captured by trade openness alone. Fourth, the theoretical model suggests that increased openness to trade and greater capital mobility may have self-reinforcing positive effects on the sacrifice ratio, although the positive correlation between the two globalization measures complicates interpreting regression results in which both measures are taken to be independent variables. When we treat both measures of international openness as independent variables, we obtain a positive coefficient estimate on the interactive effect that the two have on the sacrifice ratio, but this estimate is statistically insignificant.

Taken together, the first three conclusions provide support for concluding from crosscountry data that increased trade openness and greater capital mobility do indeed independently tend to boost the sacrifice ratio. Thus, our analysis supports the conclusion that globalization, whether through more openness to trade or greater openness to capital flows, contributes to a shallower Phillips curve. Although our theoretical framework indicates that there is also a potential for interactive effects of the two globalization measures on the sacrifice ratio, 
we do not find evidence of statistically significant interacting impacts of increased trade openness and greater capital mobility.

\section{Conclusion}

This paper has developed and empirically evaluated implications of an open-economy framework exploring the separate impacts of, and interactions among trade openness and capital mobility as factors affecting the sacrifice ratio. Consistent with our theoretical model, we find evidence in cross-country data of separate effects of increased trade openness and greater capital mobility influence the sacrifice ratio. Once the conditioning effect of central bank independence is taken into account, we find that increases in both measures of international openness result in a higher sacrifice ratio. We also find evidence that greater wage duration enhances the positive sacrifice-ratio effect of more mobile capital, which is consistent with our theory's implication that the impact of greater capital mobility is positively related to the degree of wage stickiness in a nation's economy. Although our model suggests the potential for greater capital mobility to enhance the sacrifice-ratio impact of increased trade openness, the empirical results do not necessarily provide support for this prediction.

Overall, our analysis of cross-country data supports the conclusion that the forces of globalization-whether manifested as from increased openness to international trade or greater mobility of capital-tend to raise the sacrifice ratio. In our view, future work examining the impact of globalization on the sacrifice ratio should focus on country-specific data [see, for instance, early work along these lines in Ball (2006) and Sbordone (2007)]. It remains to be seen to what extent increased trade openness and greater capital mobility affect the inflation sensitivity of output and the slope of the Phillips curve within individual nations.

\section{Notes}

†. J. P. Daniels. Department of Economics, Marquette University, Straz Hall, P.O. Box 1881, Milwaukee, WI 53201-1881, USA. E-mail: Joseph.Daniels@marquette.edu

‡. D. D. VanHoose. Hamkamer School of Business, Baylor University, P.O. Box 8003, Waco, TX 76798-8003, USA. E-mail: David_VanHoose@baylor.edu

1. There can be crucial differences between the ultimate policy implications of sticky-price versus stickywage models, however, because in the former models a portion of firms in the economy hold prices fixed, typically in light of menu costs, even after monetary policymakers have engaged in policy actions, whereas in the latter models monetary policy 
actions take place before prices are set, and firms optimally choose not to adjust prices fully in light of wage rigidities.

2. The derivation of this condition mirrors Benavie (1983). From Eq. 3 the net trade balance is $\eta\left(p^{*}+s-p\right)-\beta y+\beta y^{*}$. If the flow demand for domestic bonds is given by $b^{d}=\varphi y^{*}+\theta \chi r-\theta \varpi\left(r^{*}+s_{+1}^{e}-s\right)+p^{*}+s$, and if the flow demand for foreign bonds is given by $b^{f}=\mu y-\theta \vartheta r+\theta v\left(r^{*}+s_{+1}^{e}-s\right)+p$, then the net domestic capital inflow is defined as $b^{d}-b^{f}=\left(p^{*}+s-p\right)-\mu y+\theta \kappa r-\theta \psi\left(r^{*}+s_{+1}^{e}-s\right)+\varphi y^{*}$, where $\kappa \equiv \varpi+v$ and $\psi \equiv \chi+\vartheta$. Adding the expression for the trade balance to the net capital inflow yields Eq. 5.

3. Sacrifice ratios typically are computed using CPI inflation rates, which arguably incorporate effects of exchange-rate variations as well as changes in the domestic price level. Examining the effects of changes in $\beta$ and $\theta$ on $\frac{\partial y}{\partial s}$ yields the same prediction regarding the effect greater trade openness on the sacrifice ratio and does nothing to resolve the theoretical ambiguity of the sacrifice-ratio impact of increased capital mobility.

4. Aizenman and Noy estimate an $87 \%$ linear feedback between trade openness and financial openness. The simple bilaterial correlation between trade openness and capital mobility in our data is $79 \%$.

5. One way to deal with the colinearity in our model is to test the joint significance of the related variables. We do so in a model that includes trade and capital as well as their interaction with CBI. In this model, trade and capital are jointly significant with a p-value of $3 \%$. We also combine models 4 and 5 in Table 2 and test the joint significance of capital, capital $^{\star} W d u r$, and capital ${ }^{\star} \mathrm{CBI}$. The $p$-value of the test of joint significance (two-tailed test) is $17 \%$.

\section{References}

Aizenman J, Noy I (2004) On the two way feedback between financial and trade openness, NBER Working Paper 10496

Bade R, Parkin M (1982) Central bank laws and monetary policy. Manuscript, University of Western Ontario

Ball $L$ (1994) What determines the sacrifice ratio? In: Mankiw NG (ed) Monetary policy.

University of Chicago Press, Chicago, IL, pp 155-193

Ball L (2006) Has globalization changed inflation? NBER Working Paper 12687, November 
Barro R, Gordon D (1983) A positive theory of monetary policy in a natural rate model. J Polit Econ 91:589-610 doi:10.1086/261167

Bean C (2006) Globalization and inflation. Bank of England Quarterly Bulletin, Fourth Quarter, 468-475

Bleaney M (1999) The disappearing openness-inflation relationship: a cross-country analysis of inflation rates. Working Paper WP/99/161, International Monetary Fund, Washington, DC

Benavie A (1983) Achieving external and internal targets with exchange-rate and interest-rate intervention. J Int Money Finance 2:75-85 doi:10.1016/0261-5606(83)90008-6

Bowdler C (2004) Openness, exchange rate regimes, and the Phillips curve. Manuscript, Nuffield College, University of Oxford

Bryson J, Jensen H, VanHoose D (1993) Rules, discretion, and international monetary and fiscal policy coordination. Open Econ Rev 4(2):117-132 doi:10.1007/BF01000515

Canzoneri M, Henderson D (1991) Monetary policy in interdependent economies: a game theoretic approach. MIT Press, Cambridge, MA

Cukierman A (2004) Monetary institutions, monetary union, and unionized labor markets: some recent developments. In: Beetsma R, Favero C, Missale A, Muscatelli A, Natale F, Tirelli $\mathrm{P}$ (eds) Monetary policy, fiscal policies, and labor markets: macroeconomic policymaking in the EMU. Cambridge University Press, Cambride, UK, pp 299-326

Cukierman A (1992) Central bank strategy, credibility and independence: theory and evidence. MIT Press, Cambridge MA

Daniels J (1997) Optimal sterilization policies in interdependent economies. J Econ Bus 49:4360 doi:10.1016/S0148-6195(96)00040-9

Daniels J, VanHoose D (2006) Openness, the sacrifice ratio, and inflation: is there a puzzle? J Int Money Financ 25:1336-1347 doi:10.1016/j.jimonfin.2006.09.005

Daniels J, Nourzad F, VanHoose D (2005) Openness, central bank independence, and the sacrifice ratio. J Money Credit Bank 37:371-379 doi:10.1353/mcb.2005.0020

Daniels J, Nourzad F, VanHoose D (2006) Openness, centralized wage bargaining, and inflation. Eur J Polit Econ 22:969-988 doi:10.1016/j.ejpoleco.2005.09.001

Duca J (1987) The spillover effects of nominal wage rigidity in a multisector economy. J Money Credit Bank 19:117-121 doi:10.2307/1992251

Duca J, VanHoose D (2000) Has greater competition restrained inflation? South Econ J 66:479491 doi: $10.2307 / 1061435$ 
Duca J, VanHoose D (2001) The rise of goods-market competition and the fall of wage contracting: Endogenous wage contracting in a multisector economy. J Macroecon 23(1):1-29 doi:10.1016/S0164-0704(01)00152-5

Franzese R Jr (2002) Macroeconomic policies of developed democracies. Cambridge University Press, Cambridge, UK

Grilli V, Masciandaro D, Tabellini G (1991) Political and monetary institutions and public financial policies in the industrial countries. Econ Policy 13:341-392 doi: $10.2307 / 1344630$

Gruben W, McLeod D (2002) Capital account liberalization and inflation. Econ Lett 77:221-225 doi:10.1016/S0165-1765(02)00137-4

Gruben W, McLeod D (2004) Capital market liberalization, disinflation, and commitment. Manuscript, Federal Reserve Bank of Dallas and Fordham University 486 J.P. Daniels, D.D. VanHoose

Karras G (1999) Openness and the effects of monetary policy. J Int Money Finance 18:13-26 doi:10.1016/S0261-5606(98)00037-0

Lane P (1997) Inflation in open economies. J Int Econ 42:327-347 doi:10.1016/S00221996(96)01442-0

Loungani P, Razin A, Yuen C-W (2001) Capital mobility and the output-inflation trade-off. J Dev Econ 64:255-274 doi:10.1016/S0304-3878(00)00132-2

Razin A, Loungani P (2005) Globalization and equilibrium output-inflation trade-offs. NBER Working Paper 11641, September

Razin A, Yuen C-W (2002) The 'new Keynesian' Phillips curve: closed economy versus open economy. Econ Lett 75:1-9 doi:10.1016/S0165-1765(01)00588-2

Rogoff K (2006) Impact of globalization on monetary policy. Symposium on the New Economic Geography: Effects and Policy Implications. Federal Reserve Bank of Kansas City, Jackson Hole, Wyoming, http://www.kc.frb.org/PUBLICAT/SYMPOS/2006/sym06prg.htm

Romer D (1993) Openness and inflation: theory and evidence. Q J Econ 108:869-903 doi: $10.2307 / 2118453$

Sbordone A (2007) Globalization and inflation dynamics: the impact of increased competition. NBER Working Paper 13556, October 2007

Temple J (2002) Openness, inflation, and the Phillips curve: a puzzle. J Money Credit Bank 34:450-468 doi:10.1353/mcb.2002.0049

Terra C (1998) Openness and inflation: a new assessment. Q J Econ 113:641-648 doi:10.1162/003355398555603 
Daniels, VanHoose 17 


\section{Appendix}

Table 1: Descriptive statistics, cross-section of 16 countries (Australia, Austria, Belgium, Canada, Denmark, Finland, France, Germany, Italy, Japan, Netherlands, New Zealand, Sweden, Switzerland, United Kingdom, USA)

\begin{tabular}{ccccccccc}
\hline & SAC & CBI & Inflation & Inflations & Length & Wdur & Trade & Capital \\
\hline Mean & 0.716 & 0.496 & 8.134 & 4.604 & 2.719 & 1.404 & 0.899 & 0.084 \\
Median & 0.578 & 0.449 & 7.800 & 3.740 & 2.000 & 2.000 & 0.862 & 0.063 \\
St. Dev. & 0.928 & 0.194 & 3.983 & 2.820 & 1.386 & 0.776 & 0.414 & 0.053 \\
\hline
\end{tabular}

SAC Sacrifice ratio (Temple 2002; Daniels et al. 2005), CBI Central Bank Independence, index of central bank independence (Franzese 2002), Inflation change in GDP deflator (Temple 2002; Daniels et al. 2005), Inflation $\Delta$ drop in the rate of inflation during the given period (Temple 2002; Daniels et al. 2005), length length of disflationary period of yeasr (Temple 2002; Daniels et al. 2005), Wdur wage contract duration (Temple 2002; Daniels et al. 2005), Trade ratio of the sum of imports and exports to nominal GDP (calculated from the International Financial Statistics), Capital sum of capital inflows and capital outflows to nominal GDP (calculated from the International Financial Statistics) 
Table 2: OLS estimates of the sacrifice ratio, cross-section of 16 countries (all models omit Germany, 1973-1978, as a single outlier)

\begin{tabular}{|c|c|c|c|c|c|c|c|c|}
\hline & (1) & (2) & (3) & $(4)$ & (5) & (6) & (7) & (8) \\
\hline \multirow[t]{2}{*}{ Constant } & -0.389 & $-2.900^{* *}$ & -0.424 & -1.234 & 0.412 & -0.406 & 0.430 & -0.111 \\
\hline & 0.54 & 2.38 & 0.61 & 1.61 & 0.49 & 0.56 & 0.50 & 0.12 \\
\hline \multirow[t]{2}{*}{$\mathrm{CBI}$} & $1.284^{* *}$ & $6.559^{* * *}$ & $1.278^{* *}$ & $3.750^{* *}$ & $1.696^{* *}$ & $1.291^{*}$ & $1.701^{\star *}$ & $1.370^{* *}$ \\
\hline & 1.93 & 2.97 & 1.91 & 2.61 & 2.54 & 1.90 & 2.52 & 1.97 \\
\hline \multirow[t]{2}{*}{ Trade } & 0.076 & $3.025^{\star * *}$ & & & & -0.086 & $-0.089^{*}$ & -0.275 \\
\hline & 0.27 & 2.73 & & & & 0.17 & 0.18 & 0.45 \\
\hline \multirow[t]{2}{*}{ Capital } & & & 1.035 & $16.632^{\star *}$ & -10.662 & 1.553 & -10.131 & -2.820 \\
\hline & & & 0.57 & 2.06 & 1.44 & 0.47 & 1.28 & 0.31 \\
\hline \multirow[t]{2}{*}{ Inflation } & $0.072^{*}$ & 0.057 & $0.076^{*}$ & 0.066 & 0.066 & $0.076^{\star}$ & 0.067 & $0.076^{*}$ \\
\hline & 1.66 & 1.40 & 1.73 & 1.43 & 1.41 & 1.74 & 1.41 & 1.69 \\
\hline \multirow[t]{2}{*}{ Inflation $\Delta$} & $-0.123^{* * *}$ & $-0.095^{\star *}$ & $-0.128^{* * *}$ & -0.103 & -0.106 & $-0.131^{* *}$ & -0.109 & $-0.125^{\star *}$ \\
\hline & 2.21 & 1.72 & 2.39 & 1.43 & 1.65 & 2.21 & 1.58 & 2.08 \\
\hline \multirow[t]{2}{*}{ Length } & $0.290^{\star * *}$ & $0.249^{\star *}$ & $0.293^{\star \star \star}$ & $0.226^{* *}$ & $0.231^{* *}$ & $0.295^{\star \star \star}$ & $0.233^{\star \star}$ & $0.274^{\star \star}$ \\
\hline & 2.92 & 2.52 & 3.02 & 2.14 & 2.22 & 2.95 & 2.18 & 2.61 \\
\hline \multirow[t]{2}{*}{ Wdur } & $-0.292^{*}$ & -0.235 & -0.289 & $-0.420^{* *}$ & $-0.815^{\star *}$ & -0.280 & $-0.806^{* *}$ & $-0.288^{*}$ \\
\hline & 1.74 & 1.46 & 1.66 & 2.42 & 2.47 & 1.63 & 2.43 & 1.67 \\
\hline \multirow[t]{2}{*}{ Trade $\times \mathrm{CBI}$} & & $-6.089^{* *}$ & & & & & & \\
\hline & & 2.52 & & & & & & \\
\hline \multirow[t]{2}{*}{ Capital x Wdur } & & & & & $6.731^{*}$ & & $6.733^{*}$ & \\
\hline & & & & & 1.74 & & 1.73 & \\
\hline \multirow[t]{2}{*}{ Capital x CBI } & & & & $-32.958^{*}$ & & & & \\
\hline & & & & 1.83 & & & & \\
\hline \multirow[t]{2}{*}{ Trade $x$ Capital } & & & & & & & & 2.636 \\
\hline & & & & & & & & 0.56 \\
\hline Adjusted R2 & 0.286 & 0.382 & 0.288 & 0.348 & 0.345 & 0.289 & 0.345 & 0.294 \\
\hline F Statistics & 4.83 & 6.11 & 4.89 & 5.03 & 4.91 & 4.14 & 4.23 & 3.56 \\
\hline Observations & 57 & 57 & 57 & 57 & 57 & 57 & 57 & 57 \\
\hline
\end{tabular}

Absolute values of $t$-ratios in first row, based on robust standard errors in the second row

${ }^{*} p=0.10$

${ }^{* *} p=0.05$

${ }^{* * *} p=0.01$

Daniels, VanHoose 19 